\title{
Electromagnetic profiling of Owena Dam, Southwestern Nigeria, using very-low-frequency radio fields
}

\section{Elektromagnetno profiliranje z zelo nizkofrekvenčnim radijskim poljem na pregradi Owena v jugozahodni Nigeriji}

\author{
Cyril Okpoli* and Raphael Tijani \\ Department of Earth Sciences, Adekunle Ajasin University, Akungba-Akoko, Ondo State, Nigeria \\ *cyril.okpoli@aaua.edu.ng
}

\begin{abstract}
Very low frequency (VLF) was used to assess variations in overburden composition, bedrock lithology and the concealed basement structures within the bedrock of Owena Dam in Igbara-Oke of the Precambrian Basement Complex of Southwestern Nigeria. Five VLF-electromagnetic (EM) traverses were occupied at $5 \mathrm{~m}$ intervals. The VLF normal and filtered real component anomalies identify major geological interfaces suspected to be faults/fractured zones. The points of crossover between the real and imaginary components delineate the fractured zones, which were identified as areas of possible seepage (piping and sloughing). The internal erosion (permeability) of soil mass eventually leads to the formation of an open conduit in the soil, which may lead to failure of the embankment/dam. The fractured zones are suspected to be present at all traverses. In total, 21 fractured zones were identified along the dam embankment, with the deepest occurrence at Traverse 5 . These seepage zones cause heterogeneity in the subsurface composition, which could lead to dam failure. The result of the study suggests that VLF is an adequate method of monitoring seepages in embankment dams.
\end{abstract}

Key words: very low frequency (VLF), dam, Igbara-Oke, fault/fractured, embankment

\section{Izvleček}

Z metodo zelo nizkofrekvenčnega radijskega polja (Very Low Frequency Radio Field, VLF) smo preiskali spremenljivost sestave krovne zemljine, litologije matične kamnine in zgradbe zakrite podlage na območju nasute pregrade Owena v kraju Igbara Oke na ozemlju kompleksa predkambrijske podlage v jugozahodni Nigeriji. Izmerili smo pet profilov VLF-EM s petmetrskimi razmaki. Anomalije naravnih in filtriranih vrednosti realne komponente VLF nakazujejo večje geološke prekinitve, ki predstavljajo domnevno prelomne ali razpoklinske cone. Točke prekrivanja med realnimi in imaginarnimi komponentami indicirajo razpoklinske cone, ki utegnejo biti mesta možnega prepuščanja vode. Notranja erozija v prepustnejših delih zemljinske gmote lahko vodi do nastanka odprtih kanalov znotraj zemljine, kar bi moglo povzročiti rušenje nasute pregrade. Razpoklinske cone so nakazane v vseh profilih. Vsega skupaj smo ugotovili 21 razpoklinskih con v območju pregrade z najglobljo v profilu 5. Indicirane cone prepuščanja vode lahko povzroče motnje v sestavi zemljine, kar bi utegnilo privesti do rušenja pregrade. Raziskava kaže, da je VLF primerna metoda za ugotavljanje prepuščanja v nasutih pregradah.

Ključne besede: zelo nizko frekvenčna metoda, nasuta pregrada, Igbara-Oke, prelomi/razpoke, brežine 


\section{Introduction}

Very low frequency (VLF) method is traditionally used to study the electrical properties of the earth's crust. This method is relatively cheap and the source is always available, although its strength differs throughout the day and year. The forward and inverse plane wave modelling techniques developed for deep earth studies have been applied in shallow exploration using VLF method. A wealth of 1D [1, 2] and 2D [3] models exist for inverse modelling. Recently, full 3D models have been utilised [4, 5]. At its developmental stage, routine inversion of VLF-electromagnetic (EM) data using 1D and 2D models is usually carried out using personal computers, yet 3D inversion requires work stations because of excessive processing time.

The demand for water from the Owena Dam has increased tremendously over the years, making the facility to become grossly inadequate for the intended towns and villages, a development that has called for a much larger supply scheme. Consequently, in 1976, the Ondo State Government commissioned the design of the Owena River Dam with the objective of supplying raw water from the resulting reservoir for the existing water scheme, but this was taken over by the Federal Government of Nigeria (through the Benin-Owena River Basin Development Authority). The design of the Owena River Dam was converted to fit its multipurpose use in accordance with the functions specified by the River Basin Development Authority: irrigation of 3,000 ha of farmland, development of fisheries and generation of hydro-electric power. The dam, sited on the Owena River about $14 \mathrm{~km}$ upstream of the old Owena water scheme, was designed to create an impoundment of $362.500 \mathrm{~m}^{3}$ gross capacity, covering an area of approximately $7.38 \mathrm{~km}^{2}$ at the normal water level [6].

The existence of geological features such as faults, joints, fractures, fissures or shear zones has implications on the source and integrity of the dam. The integrity of the dam cannot be assured. The existence of the geological features such as seepage zone in bed rock and/or discontinuity in the structure itself affects the source and integrity of the dam structurally. In this case, preference is therefore given to the relevance of depth to bedrock determination, structural mapping, determination of the nature of the superficial deposit etc. [7-9]. Moreover, differentiation of lithological boundaries and determination of structural trend, among others [10], are relevant tools to give clues about the location of possible sources of water collection basins such as dams.

Geophysical methods have been used extensively in dam site investigations [11-16]. The EM is widely utilised in dam development and in delineation of seepage zones, most frequently in basement complex areas $[17,18]$. The major relevance of VLF lies in overburden thickness (depth to bedrock) estimation and basement fracture delineation. Assessing the scope and limitations of the EM method, Olorunfemi et al. [19] observed that the EM method is more relevant in the delineation of near-surface fractures than in the estimation of overburden thicknesses. The EM anomaly amplitudes were observed to be more influenced by the conductivity of the overburden (weathered layer) than the thickness. It was also observed that the EM method is not amenable to the mapping of confined fractures $[20,21]$ that are located within fresh and infinitely resistive basement rocks.

During the past decade, the EM method has become increasingly successful in the search for groundwater-collecting centres [20,22]. The method has been extensively used in dam construction and groundwater investigation in the basement and sedimentary terrains in Nigeria and Diaspora.

The EM method has been successfully used in the investigation of dam leakage in the Southwestern Basement of Nigeria [18, 23]. The VLF method has some of its applications in geophysical and geologic mapping, hydrological boundary differentiation and determination of structural trend, among others.

Geophysical techniques involving VLF-EM surveys have been used to assess variations in the overburden composition and bedrock lithology, i.e. to characterise the overburden materials and delineate the concealed basement structures within the bedrock of Igbara-Oke, Southwestern Nigeria, with the aim of determining the existence of geological structures, such as fractures, joints and faults that can cause leak- 
age in the dam, and its implication to engineering site development.

This article shows the results of evaluation of the real and filtered components of the inverted VLF data. The purpose of this study is to ascertain the integrity of the dam by mapping the conductive pathways.

\section{Description of the study area}

Owena Dam is located in Igbara-Oke, which is situated in Ifedore Local Government, Ondo State, Nigeria, which is about $24 \mathrm{~km}$ away from Akure, the capital city of Ondo State. Its geographical coordinates are $7^{\circ} 24^{\prime} 0^{\prime \prime}$ North and $5^{\circ} 3^{\prime} 0^{\prime \prime}$ East, and its original name (with diacritics) is Igbara Oke. Igbara Oke lies within the Precambrian Basement Complex of the Nigeria Basement Complex (Figure 1). Several authors have classified the southwestern Precambrian Basement Complex, in particular Oyawoye [24], McCurry [25] and Rahman [26].

The total population for the local government area was 176,372 in 2006 [27]. The study area (i.e. the Owena Dam) is accessible via numerous major and minor roads that run west-east relative to the major north-south Akure-Ilesha Road.

The climate of the study area, namely, Owena Dam, is characterised by two major seasons, the rainy and the dry seasons. The rainy season commences around March/April and ends around October/November. The dry season starts by November and ends by April.

The study area is characterised by a dendritic drainage pattern. It is the most common type of pattern in the area and the environs. The pattern looks like branches of a tree or veins in a leaf. It was observed that some of the rivers are tributary streams in the study area trending east of north, while others trend west to north. The vegetation of the study area is characterised with fairly uniform temperature and high relative humidity. The vegetation is densely evergreen because it lies within the tropical rainforest zone consisting of palm trees, bamboo trees, thick grasses and shrubs. The principal activity in the area is farming.

\section{Materials and methods}

Instruments used for VLF-EM survey

The equipment used in EM survey basically consists of one transmitting and one receiving antenna.

- The transmitter: this device transmits EM waves into the earth to generate the secondary wave.

- The receiver: the second part of the instrument is the receiver that shows high sensitivity to the EM waves generated by the earth. The output of the receiver is connected to the meter, on which the measurement can be determined and recorded.

\section{The Abem-Wadi VLF equipment}

The Wadi VLF EM unit (Abem, Stockholm, Sweden) was used for data collection. The equipment measured the real and imaginary components of the vertical to the horizontal magnetic field ratio. The Wadi equipment utilises the negative component of the EM field generated by a military radio transmitter with VLF range between 15 and $30 \mathrm{kHz}$. The military broadcast station sends primary field waves into the subsurface, which in turn sends out a weak secondary magnetic field that has been built around conductive geological structures aligned in concentric lines around the transmitting antenna. The Wadi measures the field strength and phase displacement around the conductive geological structures, e.g. faults and fractures. The Wadi instrument registers both the filtered real part, i.e. the part of the resulting field that is in phase with the primary field, and the imaginary part, which is $90^{\circ}$ out of phase with the primary field (Wadi manual; Abem).

The Wadi is sensitive to transmitters around the world, and it automatically picks the most suitable one, and in order for induction to occur, the structure must align roughly towards the transmitter.

\section{Field procedure}

The VLF method is an inductive exploration technique that is primarily used to map shallow subsurface structural features in which the primary EM wave induces current flow $[28,29]$. In principle, it utilises transmitters operating between 15 and $30 \mathrm{kHz}$ as the primary EM 


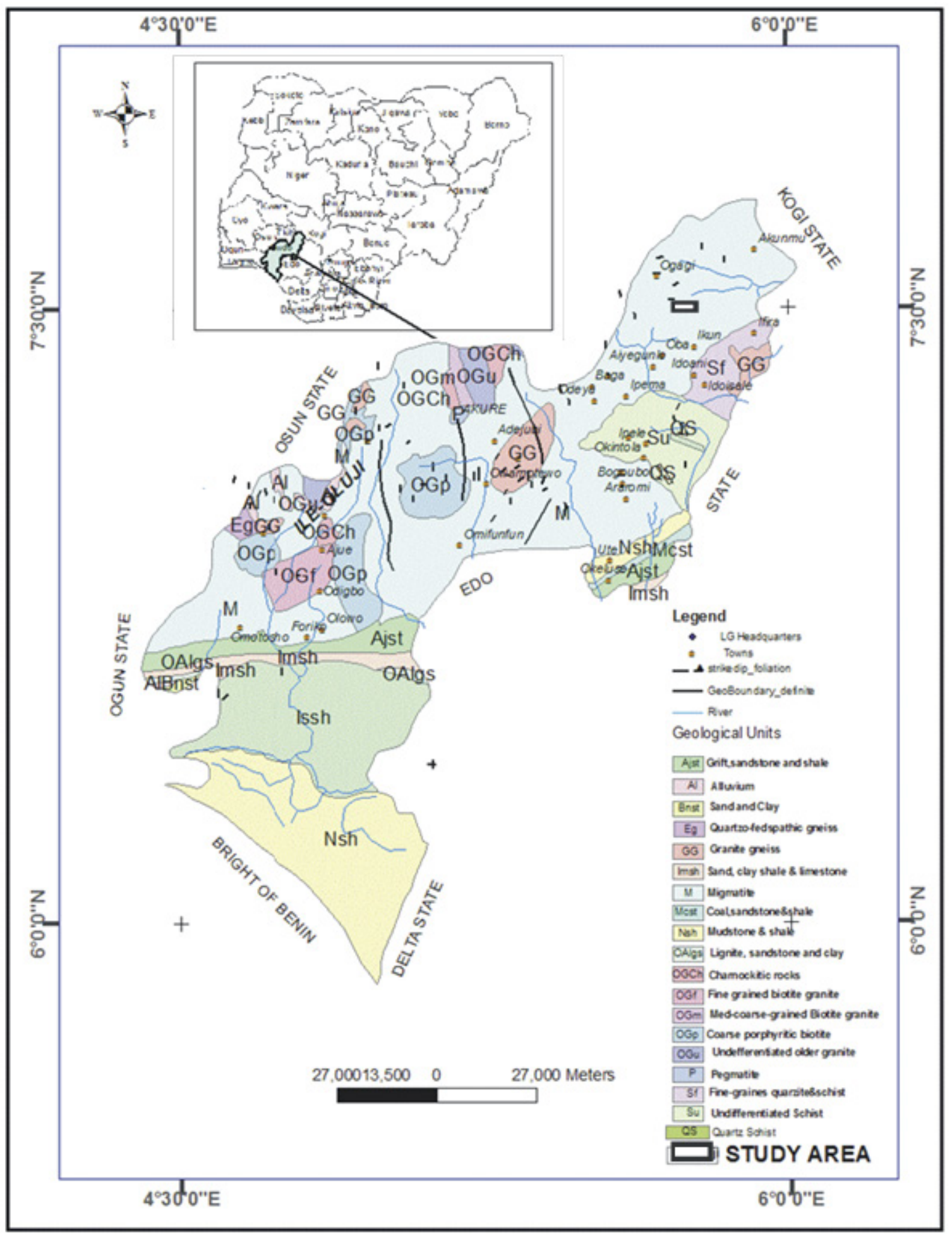

Figure 1: Geological map of Ondo State showing the study area. 


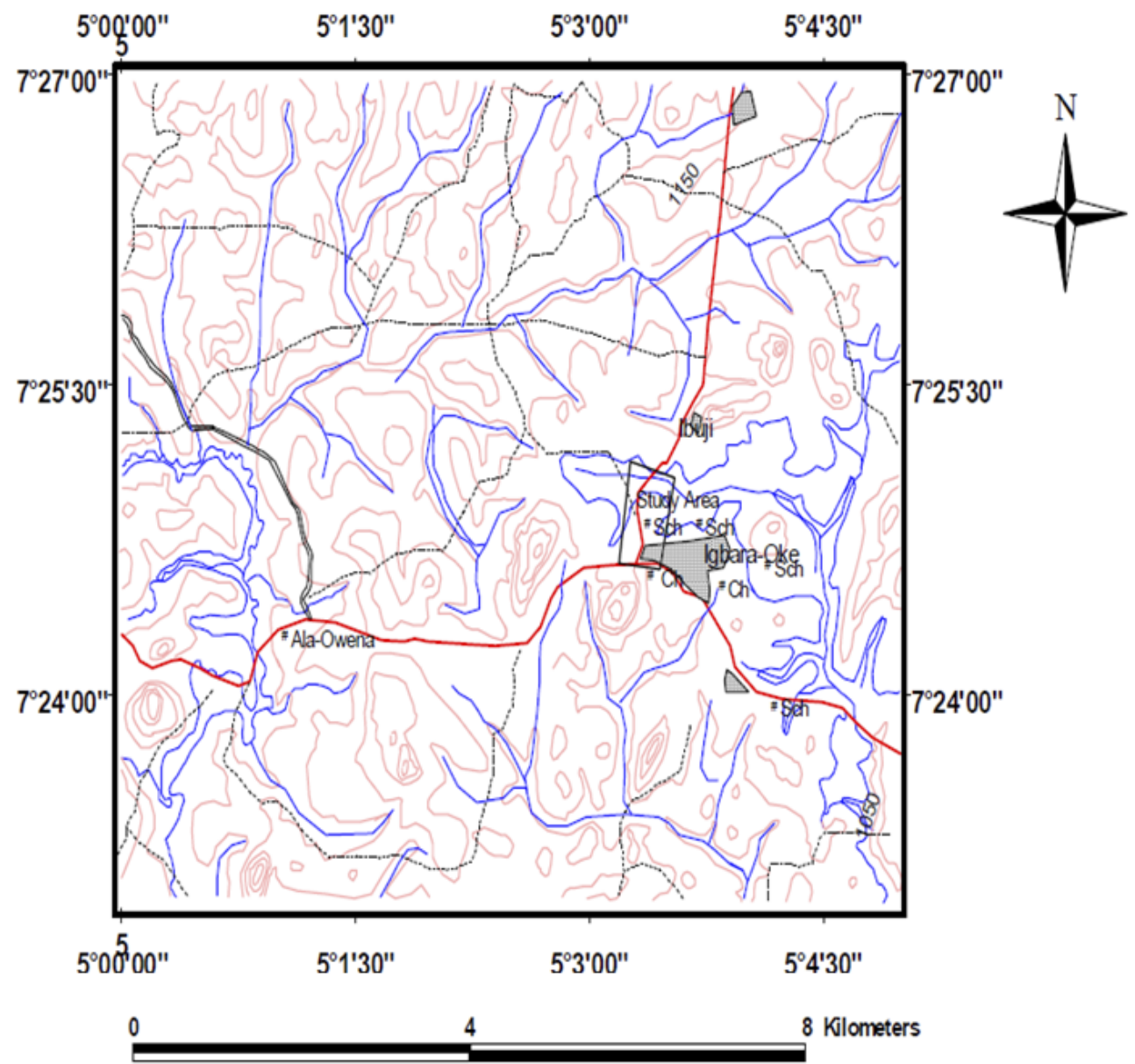

Figure 2: Modified topographic map of the study area (extracted from Akure S. W, Sheet 265; Nigeria Geological Survey Agency, 2008).

wave source. The EM waves propagating into the ground from the source $\left(H_{\mathrm{p}}\right)$ induce electric currents in any subsurface conductor in their path. The induced current produces a secondary EM field $\left(H_{\mathrm{s}}\right)$. The vector sum of the primary field $\left(H_{\mathrm{p}}\right)$ and secondary field $\left(H_{\mathrm{s}}\right)$ produces the elliptically polarised field over time.

These elliptically polarised fields consist of two components of the same frequency, but of different amplitudes and out of phase with each other. The amplitude of the component that is in phase with the primary field $H \mathrm{p}$ is the tilt angle, while the component that is out of phase with the primary field is the ellipticity. The inclination of the major axis of the polarisation ellipse from the horizontal axis is known as the tilt angle. Ellipticity $(e)$ is the ratio of the minor axis to the major axis of the polarisation ellipse of the EM fields.
A total of five traverses were established in the W-E directions, with traverse lengths of $200 \mathrm{~m}$ with regular station intervals of $5 \mathrm{~m}$.

A total of 200 station positions were occupied for VLF-EM profiling using the Wadi equipment. The transmitter used for this study is that of the National Aviation Academy at Cutler, Maine, USA, with a frequency range of $18.0-18.6 \mathrm{kHz}$. The direction of the transmitter (Tx) is northwest to southeast (NW-SE). The Wadi VLF-EM equipment detects the ratio in percentage between the vertical and horizontal components of the EM signal. The primary field is horizontal; the normal reading on the Wadi will be zero even when conductors are present. The VLF method is very sensitive to small changes in ground conductivity. 


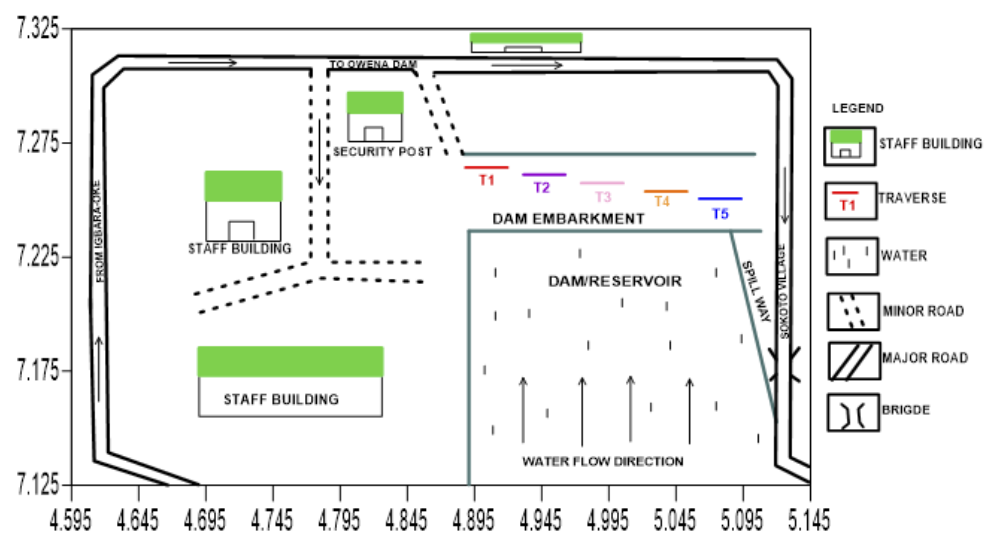

Figure 3: Data acquisition map of the study area.

\section{Data presentation}

The raw real and filtered real components of the VLF-EM anomalies were considered and are presented as profiles, while the real components of the data are usually more diagnostic of linear features when processed for qualitative interpretation. The VLF data obtained were filtered using a Karous-Hjelt (K-H) filter, processed and presented as profiles (Figure $4.1 \mathrm{a}-4.1 \mathrm{j}$ ) by plotting the filtered real and imaginary components against distance using Microsoft Excel package, while the corresponding $\mathrm{K}-\mathrm{H}$ pseudo-sections of the profiles are shown in Figure $4.1 \mathrm{a}-4.1 \mathrm{j}$, respectively. The K-H filter computes the approximate subsurface current density, giving rise to a given profile of the data, and the values are relative across the profile. The output of the $\mathrm{K}-\mathrm{H}$ filter is relative current density versus surface position at a chosen depth. Lower values of relative current density correspond to higher values of resistivity.

\section{Data interpretation}

VLF-EM interpretation is generally quantitative in nature. The real components of the VLF-EM data were transformed to filtered real data [30]. Anomalous areas were identified and gross cauterisation was applied to the anomalies (e.g. steeply dipping conductor or thickening conductive overburden). VLF-EM method is an inductive exploration technique that is used in mapping shallow subsurface structural features in which the primary EM wave induces current flow. Although both the real and quadrature components of the VLF-EM were measured, the real component data, which are usually more diagnostic of linear features, were processed for qualitative interpretation.

The VLF data, i.e. the real and imaginary components of the EM fields measured, were subjected to Fraser filtering [31] to increase the signal-to-noise ratio of the dataset and enhance the anomaly signature. The Fraser filter $(Q)$ was computed using a filter operator as shown in the following relation:

$\mathrm{Q}=(04+03) \sim(\mathrm{Qz}+\mathrm{Qi})$

where $Q$ represents the EM data and the subscripts are station positions.

This filter was applied to the real component of the VLF data to transform the dataset to the filtered real VLF data [30]. The filtered real data transform every genuine crossover or inflection point of the real anomaly to positive peaks, while reverse crossover becomes negative peak.

\section{Results and discussion}

\section{VLF-EM profile presentation}

Interpretation is done by considering the high-amplitude signals, which is diagnostic of weathered or fractured zones. The double plots of the filtered real and filtered imaginary components enable qualitative identification of the top of linear features, i.e. points of coincidence of crossovers and positive peaks of the real and filtered anomalies. Profiles 1-5 show the VLF-EM anomaly curves (real component and the filtered real component) along transverses TR1-TR5 (Figure 4.1a-4.1j). 
The linear features with positive filtered real amplitude (high) in all the profiles show areas with conductivity. The visual inspection of these anomaly curves enabled the qualitative identification of the top of linear features as points of coincidence of crossover and positive peaks of the real and filtered real anomaly curves [32].

\section{Interpretation of VLF-EM sections}

\section{Traverse 1}

In Figure 4.1a, fracture zones were located at station positions of $7,9,12,15,18,21,23,25$, and $30 \mathrm{~m}$. The fracture zones at station positions of 7-12 $\mathrm{m}$ are the shallowest, while conductors (fracture zone) at $25 \mathrm{~m}$ appear to be the deepest, with an amplitude of $-8 \mathrm{~m}$. In Traverse 1 , it can be deduced that nine fractured zones were delineated, among which five fractured zones (F1-F5) show a deep trend of the conductors. These negative peaks, mapped as fractures on the filtered real component, are zones of interest for groundwater abstraction in the basement complex terrain. The asymmetry of these conductive anomalies suggests that the conductive structures are dipping. Furthermore, the anomaly patterns exhibit varying amplitudes, which are controlled by the depth of the body to the surface, its geometry and attitude.

The VLF-EM raw real data were converted to the pseudo-section using the $\mathrm{K}-\mathrm{H}$ filter. Visual inspection of this section allows the determination of depth of occurrence, width and dip of the body. From Figure 4.1b, the attitude of the body, the length of fractures and the depth to top and bottom of the fractures can be determined. The presence of cross-cutting fractures can be identified, and the widths of the fractures are moderately thick. Figure $4.1 \mathrm{~b}$ shows the corresponding $\mathrm{K}-\mathrm{H}$ pseudo-section of Profile 1. The pseudo-section is a measure of the conductivity of the subsurface as a function of depth. The conductivity is shown as colour codes, with conductivity increasing from left to right (i.e. from negative to positive). Different features of varying degrees of conductivity trending in different directions were delineated on the section; for instance, between station positions of 5 and $12 \mathrm{~m}$, a dome-like highly conductive body trending in the W-E direction is shown with an approximate depth of 4-6 m. It also occurred between the station positions of 15 and $32 \mathrm{~m}$, exceeding a depth of $4 \mathrm{~m}$, and also at the station position of $37 \mathrm{~m}$ between depths of 2 and $3 \mathrm{~m}$, indicating a highly conductive body. These zones are considered to be highly conductive and therefore can act as leakage zones. Generally, several other closures of conductive bodies are present on the eastern part of the section, with each conductive body coinciding with the points already identified on the profile as fractures.

\section{Traverse 2}

In Figure 4.1c, fracture zones appeared as the deepest at the station position of $7 \mathrm{~m}$, with amplitude of $-10 \mathrm{~m}$ and station positions of 4 and $9 \mathrm{~m}$ seem to be in the same amplitude range of $-6 \mathrm{~m}$, indicating fracture zones. At station positions of 25 and $30 \mathrm{~m}$, the conductors tend to be very shallow and are with uniform amplitude of $-3 \mathrm{~m}$. These zones are considered to be highly conductive (F6-F7) and therefore can act as leakage zones. Fractured zones result in seepage, which is normally due to piping and sloughing. The internal erosion of soil mass eventually leads to the formation of an open conduit in the soil, which may lead to failure of the embankment/dam.

The VLF-EM raw real data were converted to the pseudo-sections using the $\mathrm{K}-\mathrm{H}$ filter. Visual inspection of this section allows the depth of occurrence, width, and dip of the body to be determined. From Figure 4.1d, the attitude of the body, the length of fractures and the depth to top and bottom of the fractures can be determined. The presence of cross-cutting fractures can be identified, and the widths of the fractures are moderately thick. Figure $4.1 \mathrm{~d}$ shows the corresponding $\mathrm{K}-\mathrm{H}$ pseudo-section of Traverse 2 . The pseudo-section is a measure of the conductivity of the subsurface as a function of depth. The conductivity is shown as colour codes, with conductivity increasing from left to right (i.e. from negative to positive). Different features of varying degrees of conductivity trending in different directions were delineated on the section at station position of 7-10 m, which shows an oval-shaped highly conductive body between the depths of 2 and $5 \mathrm{~m}$. Station 


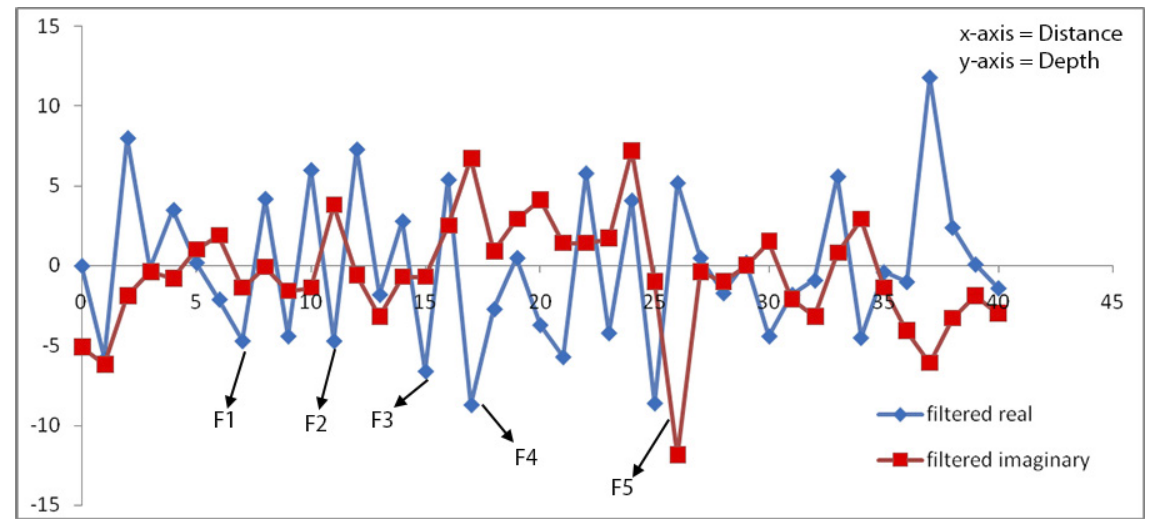

Figure 4.1a: VLF-EM profile along Traverse 1.
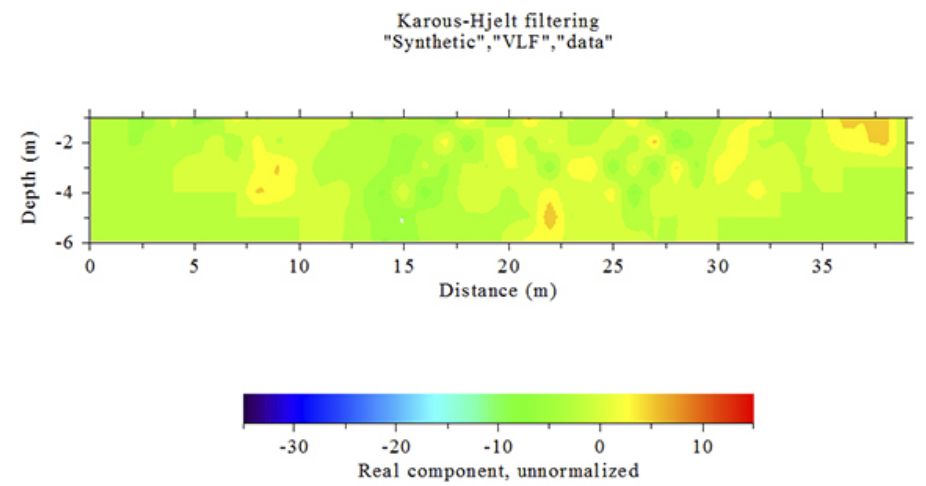

Figure 4.1 b: Karous-Hjelt pseudo-section of the inverted VLF-EM real component of the profile along Traverse 1.

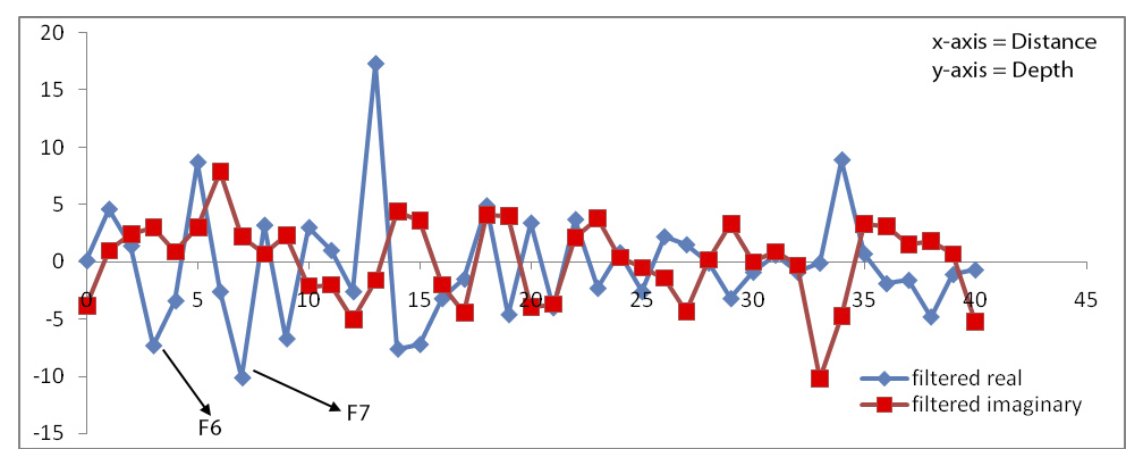

Figure 4.1c: VLF-EM profile along Traverse 2.
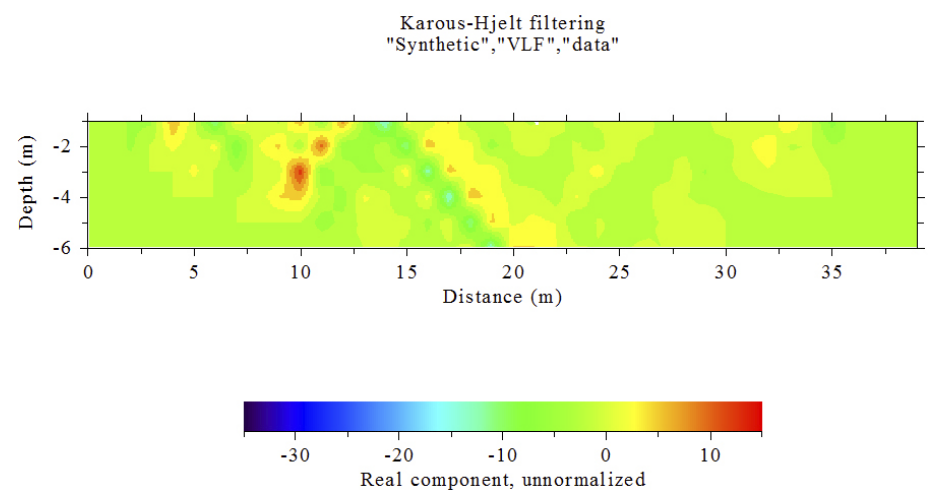

Figure 4.1d: Karous-Hjelt pseudo-section of the inverted VLF-EM real component along Traverse 2. 


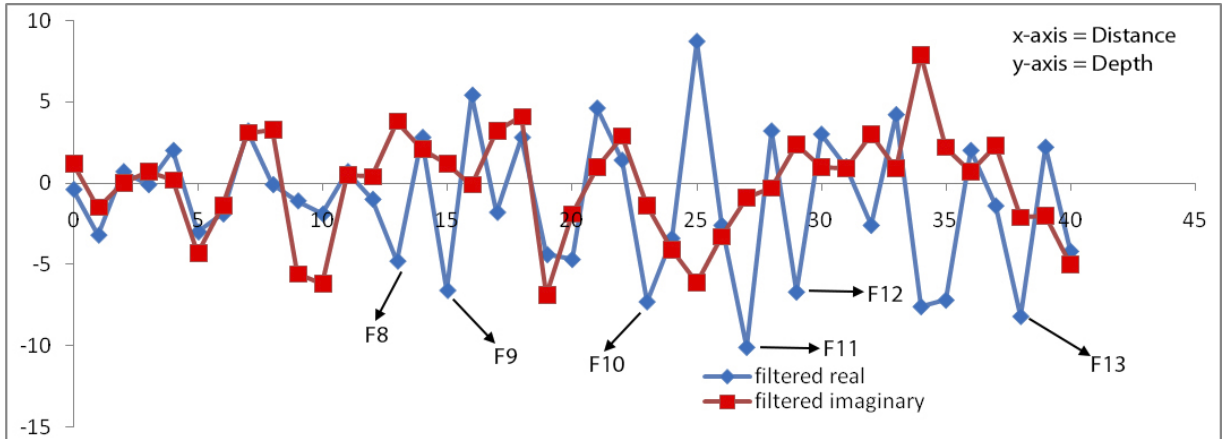

Figure 4.1e: VLF-EM profile along Traverse 3.
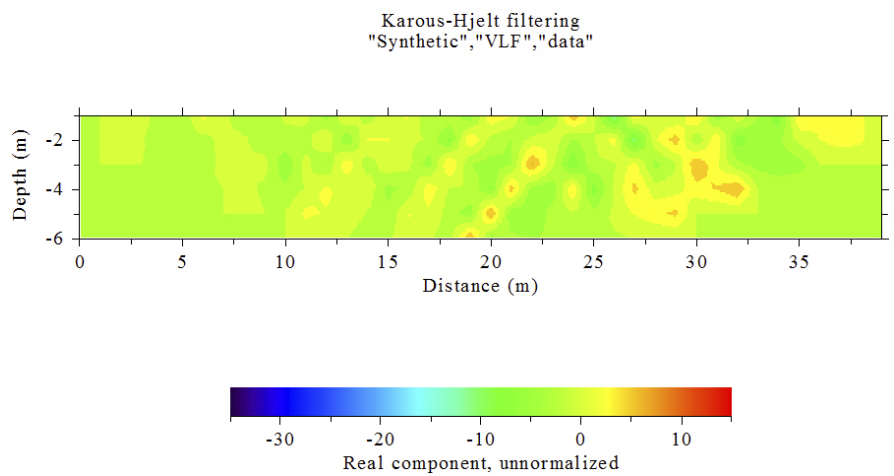

Figure 4.1f: Karous-Hjelt pseudo-section of the inverted VLF-EM real component along Traverse 3.

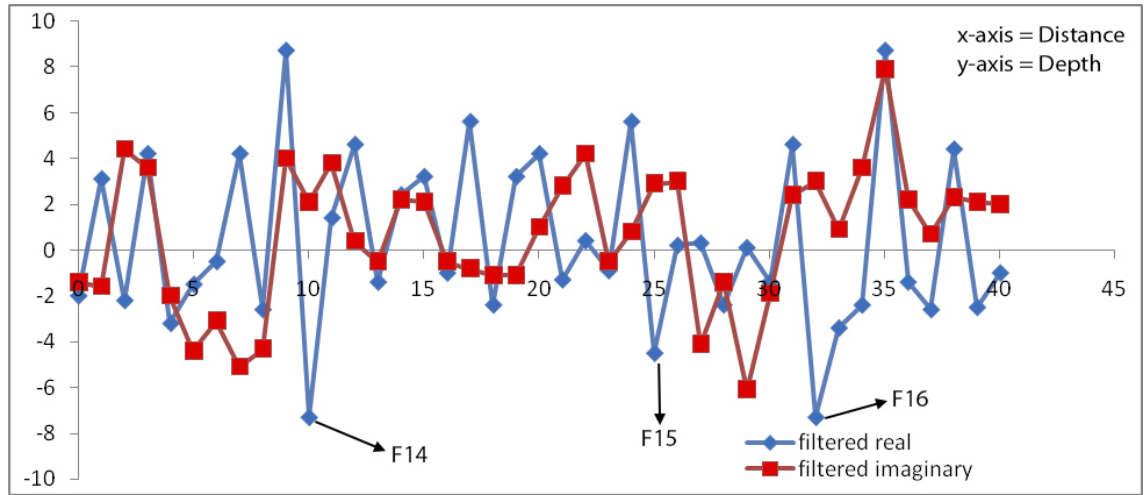

Figure 4.1 g: VLF-EM profile along Traverse 4.

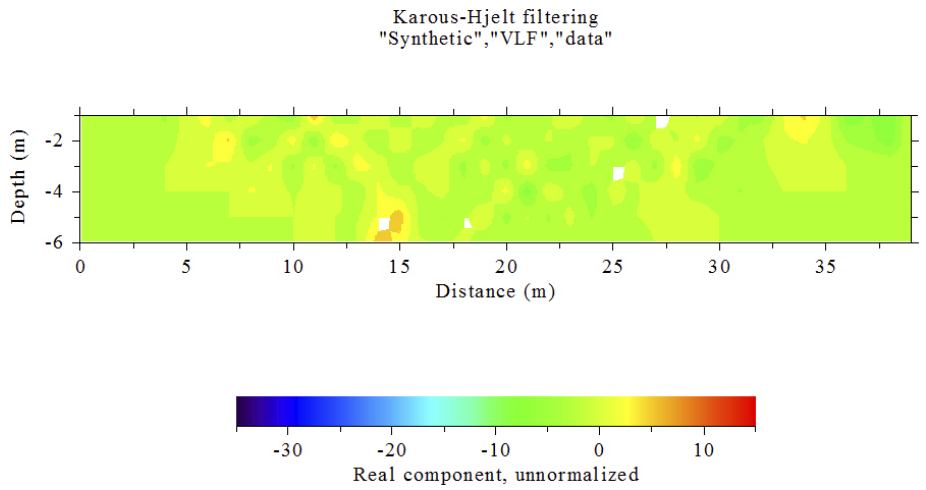

Figure 4.1 h: Karous-Hjelt pseudo-section of the inverted VLF-EM real component along Traverse 4. 


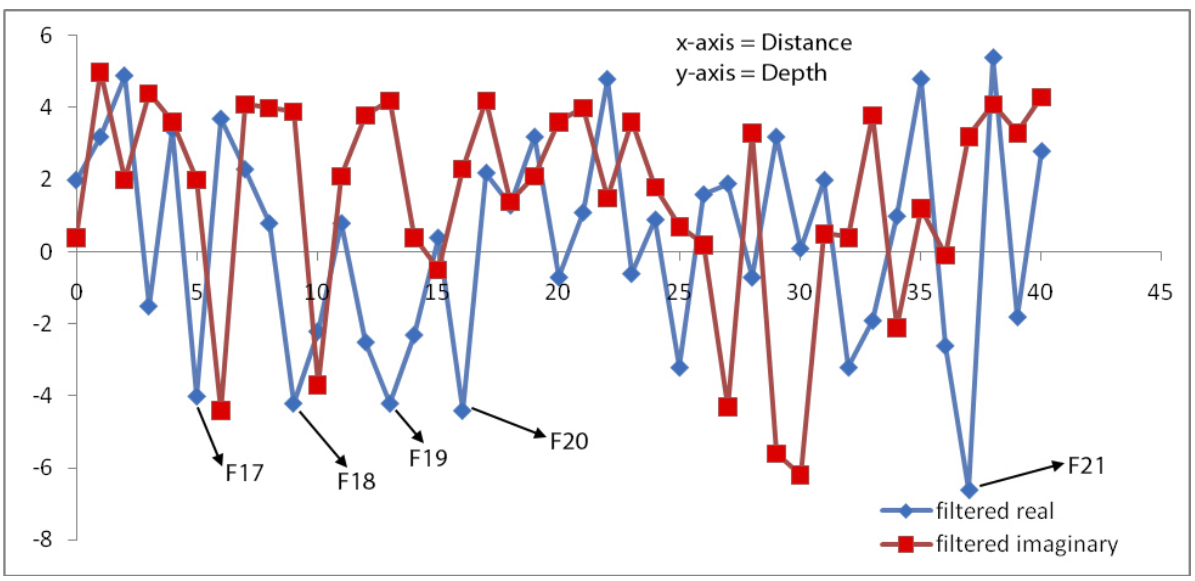

Figure 4.1i: VLF-EM profile along Traverse 5..

Karous-Hjelt filtering
"Synthetic","VLF","data"
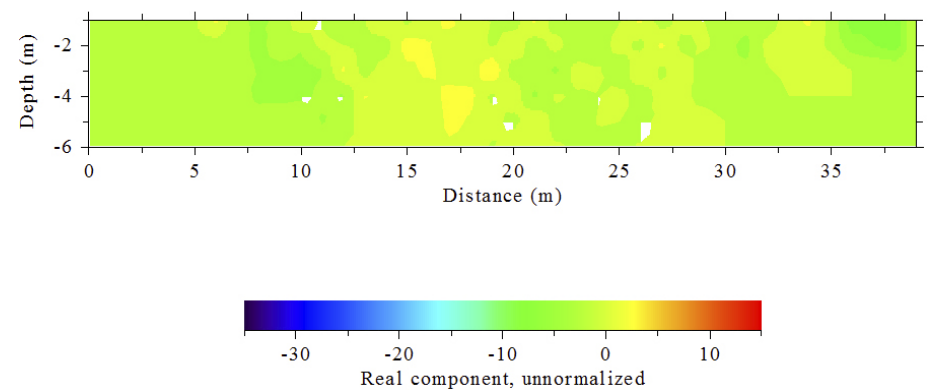

Figure 4.1j: Karous-Hjelt pseudo-section of the inverted VLF-EM real component along Traverse 5.

position of 15-22 $\mathrm{m}$ shows a linear conductive body exceeding the depth of $6 \mathrm{~m}$ at the central part of the pseudo-section.

\section{Traverse 3}

Figure 4.1e shows conductors (fracture zone) at the station position of $10 \mathrm{~m}$ with amplitude of $-3 \mathrm{~m}$ and at station position of $32 \mathrm{~m}$ with the same range of amplitude of $-3 \mathrm{~m}$. Deepest fractured zone occurred at the station position of $27 \mathrm{~m}$ with amplitude of $-10 \mathrm{~m}$; station position of 35-37 m shows a slightly deep conductor with amplitude of $-6 \mathrm{~m}$. The fractured zones identified in these traverses (F8-F13) result in seepage, which is normally due to piping and sloughing. Piping leads to dislodgement of particles from the soil structure, leading to the rearrangement of fines into the void between larger particles.

The VLF-EM raw real data were converted to the pseudo-section using the K-H filter. Visual inspection of this section allows depth of occurrence, width and dip of the body to be de- termined. From Figure 4.1f, the attitude of the body, the length of fractures and the depth to top and bottom of the fractures can be determined. The presence of cross-cutting fractures can be identified and the widths of the fractures are moderately thick. Figure $4.1 \mathrm{f}$ shows the corresponding $\mathrm{K}-\mathrm{H}$ pseudo-section of Traverse 3. The pseudo-section is a measure of the conductivity of the subsurface as a function of depth. The conductivity is shown as colour codes, with conductivity increasing from left to right (i.e. from negative to positive). Different features of varying degrees of conductivity trending in different directions were delineated on the section. The pseudo-section shows an infinite proportion of conductive body, most of which exceeded the depth of $6 \mathrm{~m}$. At station positions of $0-2 \mathrm{~m}$ and 6-9 $\mathrm{m}$, the conductive body is shown to be between the depths of 2 and $5 \mathrm{~m}$. Station position of 10-13 m shows an array of conductive bodies exceeding $6 \mathrm{~m}$ depth. Station position between 15 and $20 \mathrm{~m}$ shows two linear conductivity bodies exceeding the depth of 
$6 \mathrm{~m}$ and station position between 25 and $30 \mathrm{~m}$ has been invaded by an oval-shaped conductive body, also exceeding $6 \mathrm{~m}$.

\section{Traverse 4}

Figure 4.1g shows the fractured zones (F14F16) at station position of $10 \mathrm{~m}$ as the deepest, with amplitude of $8 \mathrm{~m}$ and the station position of $32 \mathrm{~m}$ shows a deep occurrence of fracture zones with amplitude of $7 \mathrm{~m}$. All other shallow conductors between the amplitudes of 0 and $2 \mathrm{~m}$ are not considered to be fractured zones leading to leakages; such an occurrence was shown at the station positions of $12,15,17$ and 20-24 m. These negative peaks mapped as fractures on the filtered real data are zones of interest for groundwater abstraction in basement complex terrain. The asymmetry of these conductive anomalies suggests that the conductive structures are dipping. Moreover, the anomaly patterns exhibit varying amplitudes, which are controlled by the depth of the body to the surface, its geometry and attitude.

The VLF-EM raw real data were converted to the pseudo-section using the K-H filter. Visual inspection of this section allows depth of occurrence, width and dip of the body to be determined. From Figure $4.1 \mathrm{~h}$, the attitude of the body, the length of fractures and the depth to top and bottom of the fractures can be determined. The presence of cross-cutting fractures can be identified and the widths of the fractures are moderately thick. Figure $4.1 \mathrm{~h}$ shows the corresponding $\mathrm{K}-\mathrm{H}$ pseudo-section of Traverse 4. The pseudo-section is a measure of the conductivity of the subsurface as a function of depth. The conductivity is shown as colour codes, with conductivity increasing from left to right (i.e. from negative to positive). Different features of varying degrees of conductivity trending in different directions were delineated on the section. There are several pockets of highly conductive bodies cross-cut between station positions of 5 and $10 \mathrm{~m}$, showing a descending order of conductive body with depth exceeding $6 \mathrm{~m}$ at the station position of $11 \mathrm{~m}$. The section also shows a conductive body with depth exceeding $6 \mathrm{~m}$, while at station position of $15 \mathrm{~m}$, it indicates a linear conductive body starting from 2 to $6 \mathrm{~m}$. In addition, a tiny linear conductive zone was indicated at station position of $17 \mathrm{~m}$.

\section{Traverse 5}

Figure 4.1i shows fracture zones at considerable depths relevant for the existence of seepage along the dam embankment. All the fractures in this traverse are said to be very deep, with the exception of that at station position of 20-22 m having shallow conductors. The existence of fractured zones occurred at station positions of $3,5,10,14,15,25,32,36$ and $39 \mathrm{~m}$, making a total of nine fracture zones that were delineated. They all exceeded the amplitude of $4 \mathrm{~m}$. These negative peaks, mapped as fractures on the filtered real data, are zones of interest for groundwater abstraction in basement complex terrain. The asymmetry of these conductive anomalies suggests that the conductive structures are dipping. Furthermore, the anomaly patterns exhibit varying amplitudes, which are controlled by the depth of the body to the surface, its geometry and attitude.

The VLF-EM raw real data were converted to the pseudo-section using the $\mathrm{K}-\mathrm{H}$ filter. The visual inspection of this section allows depth of occurrence, width and dip of the body to be determined. From Figure $4.1 \mathrm{j}$, the attitude of the body, the length of fractures and the depth to top and bottom of the fractures can be determined. The presence of cross-cutting fractures can be identified and the widths of the fractures are moderately thick. Figure 4.1j shows the corresponding $\mathrm{K}-\mathrm{H}$ pseudo-section of Traverse 5. The pseudo-section is a measure of conductivity of the subsurface as a function of depth. The conductivity is shown as colour codes, with conductivity increasing from left to right (i.e. from negative to positive). Different features of varying degrees of conductivity trending in different directions were delineated on the section. Due to the high zone of fracture as shown on the VLF-EM profile along Traverse 5, the resulting effect shows an oval-shaped conductive body between the station positions of 12 and $25 \mathrm{~m}$ at depths exceeding $6 \mathrm{~m}$. Moreover, the fracture occurred between station positions of $25-30 \mathrm{~m}$ and $35 \mathrm{~m}$. The result of the pseudo-section coincides with the highly fractured zones shown on the VLF-EM profile along the traverse. 


\section{Conclusion}

Geophysical investigation was carried out on Owena Dam. The VLF-EM data were acquired along five traverses. The VLF data successfully identified relatively wide areas of conductivity by detecting the edges of conductive zones. Both the maximum differences and points of crossover between the real and imaginary curves were used to delineate the sheared/ fractured and weathered zones, which were identified as areas of fracture and possible areas of internal erosion. The results of the study suggest that the EM VLF method is an adequate method for monitoring seepages in dam embankments. The point of crossover between the real and imaginary components was used to delineate the fractured zones, which were identified as areas of possible seepage. These fractured zones result in seepages, which are normally due to piping and sloughing. Piping leads to dislodgement of particles from the soil structure, leading to the rearrangement of fines into the void between larger particles. The internal erosion of soil mass eventually leads to the formation of an open conduit in the soil, which may lead to failure of the embankment/dam. The fractured zones were identified on all five traverses. In Figures 4.1a, 4.1c, 4.1e, 4.1g and 4.1i, the evidences of fractures are designated as F1-F21. A total of 21 fractured zones were identified, with the deepest fracture lineament occurring at Traverse 5. The results presented in this study give evidence that the Owena Dam embankment is fractured and leakage could occur along permeable zones. Such defect could be responsible for dam failure. We recommend additional detailed characterisation of the Owena Dam, using other complementary geophysical methods such as ground-penetrating radar, 2D and 3D electrical resistivity and seismic refraction tomography in order to confirm the fracture zones delineated using the EM method and to elucidate the pattern of the fracture. Construction engineers should use certified standards and specifications for dam construction vis-à-vis personnel, genuine materials and tools for dam reinforcement.

\section{Acknowledgements}

Many thanks go to the Federal University of Akure, Nigeria, for the release of Abem Wadi equipment for the field work. We are grateful to the Chief Technologist, who provided expertise during the field work exercise, and to anonymous reviewers, for critical comments and suggestions that have helped greatly to improve the quality of the manuscript.

\section{References}

[1] Constable, S.C., Parker, R.L. and Constable C.G. (1987): Occam inversion: A practical algorithm for generating smooth models from electromagnetic sounding data. Geophysics; 52, 289-300.

[2] Parker, R.L., and Booker, J.R. (1996): Optimal one-dimensional inversion and bounding of magnetotelluric apparent resistivity and phase measurements. Physics of the earth and planetary Interiors; 98, 269-282.

[3] DeGroot-Hedlin, C., and Constable C.S. (1990): Occam inversion to generate smooth, two-dimensional models from magnetotelluric data. Geophysics; 55, 613-1624.

[4] Newman, G.A., Recher, B. Tezkan, B. and Neubauer, F. M. (2003): 3D inversion of a scalar radio magnetotelluric field data set. Geophysics; 68, 791-802.

[5] Siripunvaraporn, W., Egbert, G. and Uyeshima, M. (2005): Interpretation of two-dimensional magnetotelluric profile data with three-dimensional inversion: synthetic examples. Geophysical journal international; 160, 804-814.

[6] Oyhakilome G. I, Aiyesanmi A.F., Akharaiyi F.C. (2012): Water Quality Assessment of Owena multi-purpose Dam, Ondo State, Southwestern Nigeria. Journal of Environmental Protection, 3, 14-25. Published online http//dx.doi.org/10.4236/jep.2012.31003.

[7] Kurtenacker, K.S. (1934): Some practical application of resistivity measurement to highway problem. Trans. Of American Institute of Mining and Metallogical Engineering, 110, pp. 49-59.

[8] Early, K.R. and Dyer, K.R. (1964): The use of resistivity survey in foundation site underlain by Karst dolomite. Geotechnique; 14, pp. 341-348.

[9] Olorunfemi, M.O. and Mesida, E.A. (1987): Engineering Geophysics and its Application in Engineering Site Investigation. (Case Study from Ile-Ife Area). The Nigerian Engineer; 22(2), pp. 57-66. 
[10] Olorunfemi, M.O. and Opadokun M.A. (1987): On the Application Of Surface Geophysical Measurement in Geological Mapping The Basement Complex Of Southwestern Nigeria As a Case Study: Journal of Africa Earth Science; 6, pp. 287-291.

[11] Artsybashev, V.A. (1973): Geophysical Investigation of Oyimo dam site, Ikare, Western Nigeria. (Unpublished report) Department of Geology.University of Ife.

[12] Ako, B.D. (1976): An integration of Geophysical and Geological data in Dam site Investigation. The Case of Opa Dam. Jour. Min. Geol., 13(1), pp. 1-6.

[13] Artsybashev, V.A. and Azeeze, L.O. (1977): Geophysical Investigation of Oyile dam site, Ilesha. Journal of Mining and geology, 14(2), 44-46.

[14] Kilty, K.T., Norris, R.A., McLamore, W.R., Hennon, K.P. and Euge, K. (1986): Seismic Refraction at Horse Mesa dam: An application of the generalized reciprocal method. Geophysics; 51(2), pp. 266-275.

[15] Annor, E.A., Olasehinde, P.L. and Pal, P.C. (1989): A geological evaluation of a Prospective site for a Weir in the River Oyin, Ilorin, Nigeria. Zangew. Geowiss, 8, 83-90.

[16] Ojo, J.S. and Olorunfemi, M.O. (1995): Geoelectric Mapping of a Near Vertical Contact: A case study Around Erusu, Ikare Area, South-Western Nigeria. Journal of Mining and Geology, 13(2), pp. 151-153.

[17] Hazell J. R, (1988): The location of Aquifer in Crystalline Rock and Alluvium in Northern Nigeria. Symposium of Training workshop of Groundwater Resources of Nigeria Using Combined Electromagnetic and Resistivity Techniques. Quarterly Journal of Engineering Geology; 21, pp. 159-175.

[18] Olayinka, A.I. (1990): Electromagnetic Profiling and Resistivity Soundings in groundwater investigation near Egbeda - Kabba, Kwara State. Journal of Mining and Geology; pp. 243-250.

[19] Olorunfemi, M.O., Dan Hassan. M. A and Ojo, J.S. (1995): On the Scope and Limitations of Electromagnetic Method in Groundwater Prospecting in a Basement Complex Area - A Case Study. Journal of African Earth Sciences; 31(2), 151-163.

[20] Olorunfemi, M.O. and Fasuyi, S.A. (1993): Aquifer Types and the Geoelectric of part of the Central Basement Terrain of Nigeria (Niger State). Journal of African Earth Sciences; 16, 309-317.
[21] Okpoli, C.C. (2013): Borehole logs and physic-chemical investigation of some presumptive springs in Akoko, southwestern Nigeria. Environmental research, engineering and mgt; 3(65), pp. 40-48.

[22] Olayinka, A.I. and Olorunfemi, M.O. (1992): Determination of Geoelectric Characteristics of Okene area and Implication for 6 borehole Siting. Journal of Mining and Geology, pp. 403-414.

[23] Olorunfemi, M.O. and Olorunniwo, M.A. (1985): Geoelectric Parameters and Aquifer Characteristics of some parts of Southwestern Nigeria. Geologia Applicato, E Idrogeologia2, XX, Part 1, pp. 99-109

[24] Oyawoye. M.O. (1964): The Geology of the Nigerian Basement Complex - A survey of our present knowledge of therm. Jour. Of Min.Geo.And Intel.; 1(2), pp. 87-193.

[25] McCurry, P. (1976): The Geology of Precambrian to lower Paleozoic rocks of Northern Nigeria - a review. In Kogbe C.A. (Ed). Elizabeth publication Co. Ibadan, Nigeria, pp. 15-38.

[26] Rahman, M.A. (1988): Recent Advances in Study of the Basement Complex of Nigeria. In Precambrian Geology of Nigeria. Published by Geological Survey of Nigeria, Kaduna South, pp. 11-43

[27] National Population Commission (2009): Population Distribution By Sex, State, LGA and Senatorial District; 3, pp. 45.

[28] Singha, A.K. (1990): Interpretation of Ground VLF-EM data In terms of Inclined Sheet-Like Conductor Model PAGEOPH; 132(4), pp. 733-755

[29] Kaikkonnen, P. and Sharma S.P. (1997): Delineation of near Surface Structures Using VLF and VLF-R Data an insight From the Joint Inversion Result. The Leading Edge; 16(11), pp. 1683-1689.

[30] Karous, M.R. and Hjelt, S.E. (1963): Linear Filtering of VLF Dip. Angle Measurements. Geophysical Prospecting; 31, 782-794.

[31] Fraser (1969): Dc Fraser Contouring of VLF-EM data. Geophysics; 34, pp. 958-967

[32] Adiat, K.A. N., Adelusi, A.O. and Ayuk, M.A. (2009): Relevance of Geophysics in Road Failures Investigation in a Typical Basement Complex of Southwestern Nigeria. Department of Applied Geophysics, Federal University of Technology, PMB 704, Akure, Nigeria. 


\section{Appendix}
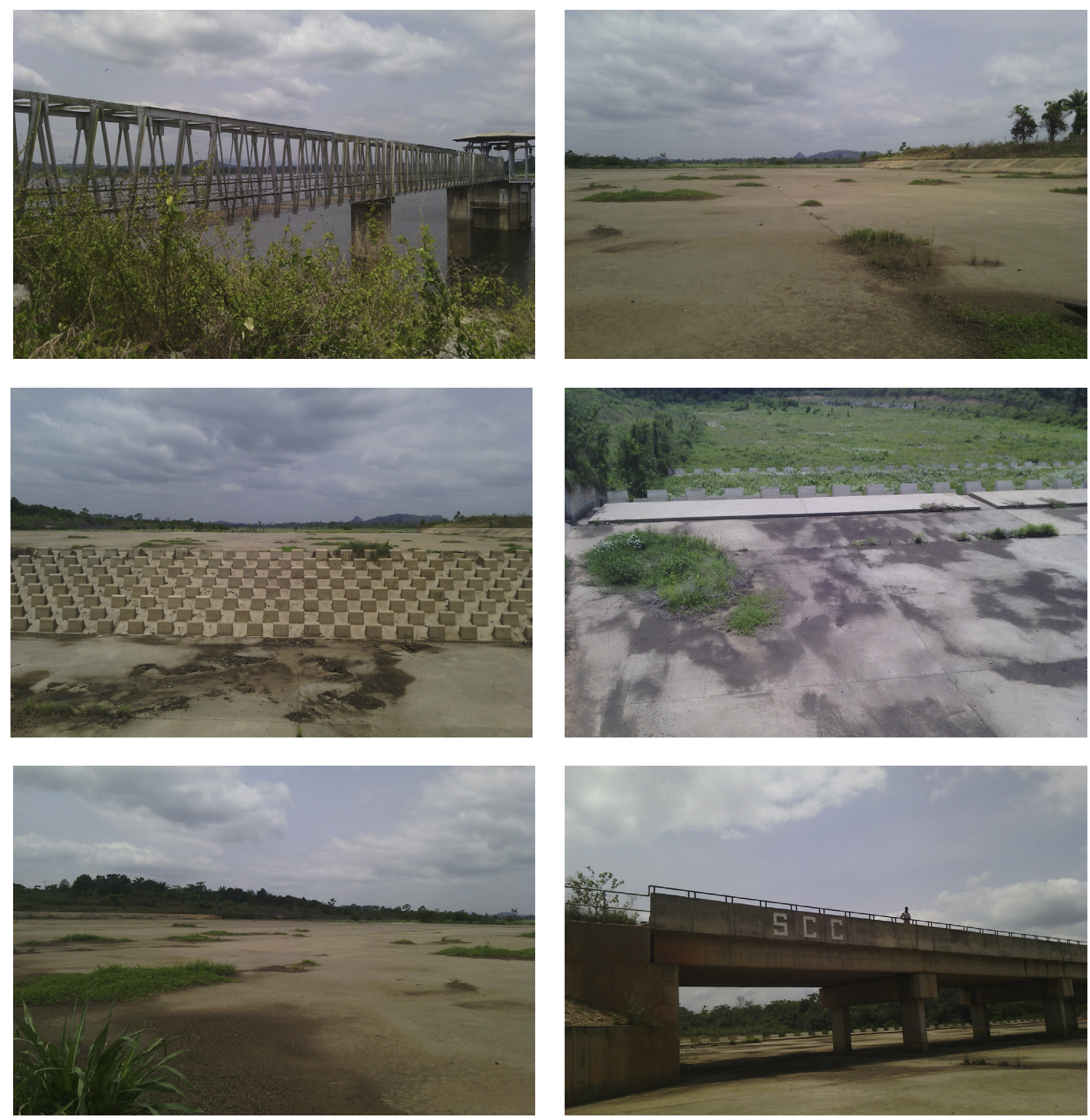

Figures: Photographs showing the dam site and wet areas. 